\title{
Effect of silicon on aphid populations and wheat yield in Minas Gerais, Brazil
}

\section{Efeito do silício em populações de afídeos e produtividade de trigo em Minas Gerais, Brasil}

\author{
Gabriel Fernandes Rezende ${ }^{1 *}$; Marcus Vinicius Sampaio ${ }^{2}$; Beliza Queiroz Vieira \\ Machado $^{1}$; Diego Tolentino de Lima ${ }^{3}$; David Nataren Perdomo'; Fernando Juari \\ Celoto $^{2}$; Carlos Juliano Brant Albuquerque ${ }^{4}$; Eduardo José Myaki Silva ${ }^{5}$; Reinaldo \\ Silva de Oliveira ${ }^{6}$; Hamilton Seron Pereira ${ }^{2}$
}

\section{Highlights:}

Insect population dynamics vary between regions, depending on environmental conditions.

Insect population is affected by weather conditions.

Silicon application did not reduce aphid populations in wheat plants in the field.

The hectoliter weight varied between regions and cultivars of wheat.

Sitobion avenae is the most abundant wheat aphid species in Brazilian savannah in Minas Gerais.

\begin{abstract}
The area cultivated with wheat has been increasing in the savannahs of the state of Minas Gerais, Brazil. Aphids are usually one of the main pests of wheat in many regions of the world; however, little is known about the aphid population in this new environment. The southern region of Brazil, the main wheat production area, has had several problems as a result of aphids, but aphid populations and the resulting impact on wheat production have not been investigated in these new crop production areas. Understanding control strategies to manage this insect could be essential for the "Cerrado" wheat that is grown in this area. The application of silicon $(\mathrm{Si})$ has the potential to reduce the population growth of wheat aphids; however no field studies have been reported. Hence, we evaluated the effect of Si fertilization via soil application on the aphid populations and species composition and on yield components of wheat in three locations in Minas Gerais; the experiment was repeated simultaneously in Uberlândia, at the experimental areas of UFU and IFTM, and in Montes Claros, at the experimental area of UFMG, using the cultivars BRS 264 and BRS 394. The aphids first appeared just before wheat earing; they were then sampled six times over the course of the study, seven days apart, starting from 45 days after sowing. The aphid species Sitobion avenae (Fabricius), Schizaphis graminum (Rondani), and Rhopalosiphum padi (Linnaeus) were observed in all three locations; S. avenae was the dominant
\end{abstract}

\footnotetext{
1 Discentes do Curso de Mestrado do Programa de Pós-Graduação Agronomia, Universidade Federal de Uberlândia, UFU, Uberlândia, MG, Brasil. E-mail: gabriel.f.rezende@hotmail.com; beliza_queiroz@hotmail.com; d.natharen91@gmail.com

2 Profs. Drs., Curso de Pós-Graduação Agronomia, Universidade Federal de Uberlândia, UFU, Uberlândia, MG, Brasil. E-mail: mvsampaio@ufu.br; fjceloto@ufu.br; hspereira@ufu.br

3 Discente do Curso de Doutorado do Programa de Pós-Graduação Agronomia, UFU, Uberlândia, MG, Brasil. E-mail: diegotolentino10@hotmail.com

4 Prof. Dr., Curso de Graduação em Agronomia, Universidade Federal de Minas Gerais, UFMG, Montes Claros, MG, Brasil. E-mail: carlosjuliano@ufmg.br

5 Discente do Curso de Graduação em Agronomia, UFMG, Montes Claros, MG, Brasil. E-mail:dudumyaki57@hotmail.com

6 Prof. Dr., Curso de Graduação em Agronomia, Instituto Federal do Triângulo Mineiro, IFTM, Uberlândia Campus, Uberlândia, MG, Brasil. E-mail: reinaldo@iftm.edu.br

* Author for correspondence
} 
species in all locations. The experimental area of UFU had the highest number of $S$. avenae aphids per tiller for both cultivars, while UFMG had the lowest populations. Aphid populations and wheat yield components were not affected by soil Si fertilization. There was no difference in yield as a result of location or cultivar, but the location UFU and the cultivar BRS 394 had the greatest average hectoliter weight.

Key words: Induced resistance. Sitobion avenae. Triticum aestivum.

\section{Resumo}

A área cultivada com trigo tem aumentado no cerrado presente no estado de Minas Gerais. Afídeos são frequentemente a principal praga dessa cultura em várias regiões do mundo porém, pouco se sabe a respeito de população de afídeos nesse novo ambiente. A região sul do Brasil, principal produtora de trigo, relatou vários problemas resultantes da presença de afídeos, mas as populações de pulgões e os seus impactos na produção do trigo ainda não foram investigados nesta nova área de produção. Portanto, é necessário conhecer a interação sobre pragas, culturas, e paisagens. Entender estratégias de controle para gerenciar esse inseto pode ser essencial para o trigo "Cerrado". A aplicação de silício ( $\mathrm{Si}$ ) tem o potencial de reduzir o crescimento populacional de pulgões do trigo, porém não há relatos de estudos de campo. Nós avaliamos os efeitos da aplicação via solo de Si sobre populações de afídeos e sobre a composição de espécies, além de componentes de produtividade em três localidades em Minas Gerais. $\mathrm{O}$ experimento foi repetido simultaneamente em Uberlândia, nas áreas experimentais da UFU e do IFTM, e em Montes Claros, na área experimental da UFMG, utilizando as cultivares BRS 264 e BRS 394. Os primeiros pulgões ocorreram antes da formação da espiga, e os mesmos foram amostrados seis vezes ao longo do estudo, com sete dias de intervalo, iniciando 45 dias após a semeadura. As espécies de afídeo Sitobion avenae (Fabricius), Schizaphis graminum (Rondani) e Rhopalosiphum padi (L.) foram observadas nos três locais e $S$. avenae foi a espécie dominante em todos os locais. A área experimental da UFU apresentou o maior número de pulgões de $S$. avenae por perfilho para as duas cultivares, enquanto a UFMG apresentou as menores populações. As populações de afídeos e os aspectos de produção do trigo não foram afetados pela fertilização de Si no solo. Não houve diferenças de produtividade para a localização ou cultivares, mas a área de UFU e a cultivar BRS 394 tiveram o maior peso médio hectolitro.

Palavras-chave: Indução de resistência. Sitobion avenae. Triticum aestivum.

\section{Introduction}

The element silicon ( $\mathrm{Si}$ ), after it is absorbed by plants, is accumulated on leaf surfaces and sap-conducting vessels, especially in so called "accumulating plants", such as species of Poaceae (Ma \& Takahashi, 1990a,b; Marafon \& Endres, 2011). Such Si accumulations sometimes increase the plant's resistance to pest and pathogen attacks, and its tolerance to water stress. Silicon also plays a role in plant physiological processes and can stimulate the production and release of natural defense compounds, reducing herbivory by insect pests (Keeping, Kvedaras, \& Bruton, 2009; A. P. Korndörfer, Grisoto, \& Vendramin, 2011; Dias et al., 2014; Santos, Junqueira, Sá, Zanúncio, \& Serrão, 2015).

Wheat is a widely consumed product in Brazil. Since national production does not meet the demand for this crop, the country is a major wheat importer. In this context, the development of new wheat cultivars adapted to the Brazilian savannah has allowed the expansion of wheat production into new regions of the country (United States Department of Agriculture [USDA], 2017; Farias et al., 2016). This increase in national wheat production is due to a greater yield of the crop, which has increased from $846 \mathrm{~kg} \mathrm{ha}^{-1}$ in the $1980 \mathrm{~s}$ to $2,737 \mathrm{~kg} \mathrm{ha}^{-1}$ in 2016/2017 (Farias et al., 2016; Companhia Nacional 
do Abastecimento [CONAB], 2017). Such gains are due to genetic breeding that has allowed expansion of wheat production into the area known as Region 4, encompassing the southeast and mid-west of Brazil. Of these areas, the southeast region has played a greater role in increasing wheat production, especially areas in the state of Minas Gerais; here, the wheat-growing regions are characterized as hot and dry, and cultivation is done at greater altitudes, using irrigation systems (Fischer, Beyerlee, \& Edmeades, 2014; Farias et al., 2016).

In order to improve crop production in these new regions, the performance of wheat cultivars must be assessed, as use of poorly adapted cultivars, combined with pest and disease attack, are the main factors reducing wheat productivity. In Brazil, the aphid species that use wheat as a host plant occur, in general, in regions with temperatures ranging from 18 to $24{ }^{\circ} \mathrm{C}$, such as southern Brazil, and parts of the southeast and mid-west regions (Salvadori \& Tonet, 2001; Stary, Sampaio, \& Bueno, 2007). Consequently, wheat-feeding aphids in Brazil are best known from the southern region, among which the main pest species are Sitobion avenae (Fabricius), Schizaphis graminum (Rondani), and Rhopalosipum padi (Linnaeus) (Rebonatto, Salvadori, \& Lau, 2015). However, studies identifying the main aphid species present in the new areas of wheat expansion are lacking. A study done in the savannah region of Triângulo Mineiro found the main aphid species in wheat fields to be Rhopalosiphum maidis (Fitch), R. padi, and S. avenae (Marsaro et al., 2016), but no investigation has been done on wheat plants themselves, and, thus, little information is available on wheat-feeding aphids in Minas Gerais.

Soil Si fertilization, in the laboratory and the greenhouse, has been found to reduce the population growth of wheat aphids (Dias et al., 2014). However, no field studies on this effect have been reported. Hence, this study evaluated the effect of soil fertilization with Si on aphid population density and species composition, and on the various yield components of wheat in different locations in Minas Gerais.

\section{Material and Methods}

The experiment was conducted in three locations in the state of Minas Gerais: two in Uberlândia (region of Triângulo Mineiro) and one in Montes Claros (northern region of Minas Gerais). In Uberlândia, the study was carried out at the Capim Branco experimental farm of the Universidade Federal de Uberlândia (UFU) (18 $18^{\circ} 52^{\prime} 02.88^{\prime \prime}$; $48^{\circ} 20^{\prime} 33.65^{\prime} \mathrm{W}$ and $822 \mathrm{~m}$ altitude) and at the experimental area of Fazenda Sobradinho of the Instituto Federal do Triângulo Mineiro (IFTM) (18 45' 59.20"S; $48^{\circ} 17^{\prime}$ 43.94'W and $642 \mathrm{~m}$ altitude). In Montes Claros, the study was carried out at the Fazenda Experimental Professor Hamilton de Abreu Navarro (FEHAN) experimental area of the Instituto de Ciências Agrárias (ICA), Universidade Federal de Minas Gerais (UFMG) (16 41'00.88'S; $43^{\circ} 50^{\prime} 23.78^{\prime \prime} \mathrm{W}$ and $626 \mathrm{~m}$ altitude). The two counties experience a climate classification of Aw, according to Köppen (1948) — a tropical climate with a rainy season in the summer and a distinct dry season in the winter, with annual average rainfall above $780 \mathrm{~mm}$ and up to $1800 \mathrm{~mm}$.

For Uberlândia, weekly average temperature and accumulated temperature data were obtained from the weather station at Fazenda Capim Branco (UFU), 310 meters from the experiment; the other site, IFTM, did not have a weather station at the farm. Weather data for Montes Claros were obtained at the UFMG weather station, 500 meters from the experimental site. No rainfall was recorded at UFU while $8.25 \mathrm{~mm}$ was recorded at UFMG. Hence, all three experimental areas were irrigated. The average temperature data were used to calculate thermal units (degree-day) accumulated by the crop above the base temperature. The base temperature of wheat shoot growth $\left(3.0^{\circ} \mathrm{C}\right.$ ) (Porter $\&$ Gawith, 1999; Luo, 2011) was used in degreeday calculations (Figure 1). 


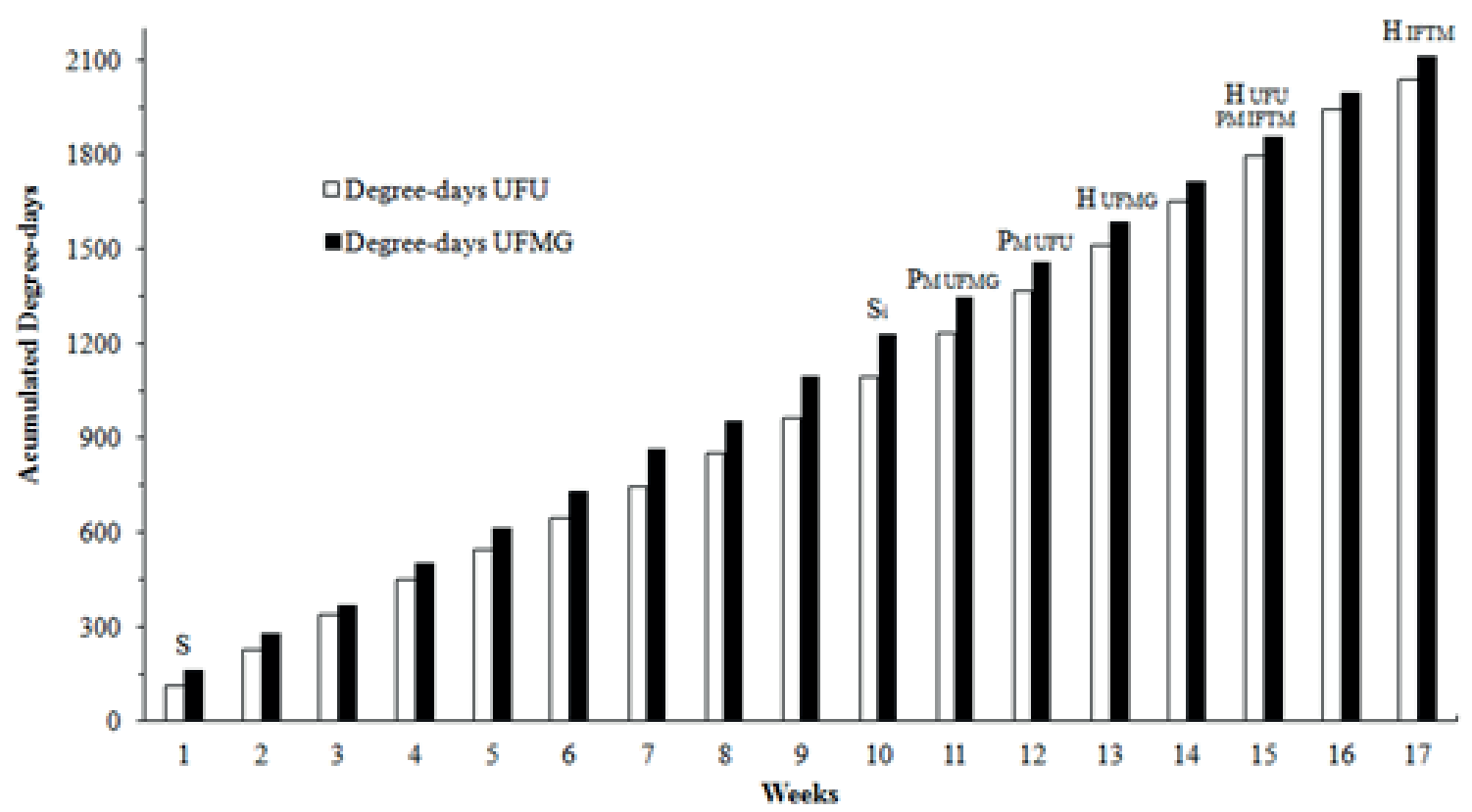

Figure 1. Weekly numbers of degrees-days $\left({ }^{\circ} \mathrm{C}\right)$ accumulated by wheat, from sowing to harvest $(01$ May to 30 September 2017), in two production location in the State of Minas Gerais, Brazil: Capim Branco Farm at UFU, in the county of Uberlândia, and the experimental area of UFMG in Montes Claros. Data of IFTM (Uberlândia county) showed in the graph represent the wheat crop cycle at this location (weeks), but not degrees-day accumulated, due the lack of temperature information at this place. S: Sowing, Weeks 7-12: Evaluation of aphid population, Si: leaf collection to determine leaf Si content, PM:kernel physiological maturation, $\mathrm{H}$ : harvest.

The experiment was conducted simultaneously in all three locations. The soil was prepared by plowing and disking on 09 May 2017 and soil treatments were applied on 10 May 2017, manually incorporating AgroSilício Plus ${ }^{\circledR}(35 \% \mathrm{CaO} ; 10 \%$ $\mathrm{MgO} ; 10.5 \% \mathrm{SiO}$ ) at $4,700 \mathrm{~kg} \mathrm{ha}^{-1}$ for the $\mathrm{Si}$ fertilization (493.5 $\mathrm{kg} \mathrm{Si}$ per hectare) treatment plots and dolomitic lime Ercal $^{\circledR}(37 \%-38 \% \mathrm{CaO}$ and $8 \%-10 \% \mathrm{MgO}$ ) at $4,700 \mathrm{~kg} \mathrm{ha}^{-1}$ for the plots with no $\mathrm{Si}$ fertilization treatment to equilibrate calcium and magnesium concentrations. Wheat was sowed manually 26 days after fertilization, to allow the amendments time to react with the soil. Soil fertilization was done with 04-30-10 (N, P, K) ratio fertilizer in the sowing furrow, at $500 \mathrm{~kg} \mathrm{ha}^{-1}$, and wheat was sowed at a density of 80 seeds per meter. Side dressing with fertilizer was done 20 days after sowing, with a $20-0-20(\mathrm{~N}, \mathrm{P}, \mathrm{K})$ ratio fertilizer at $60 \mathrm{~kg} \mathrm{ha}^{-1}$.
The experimental design used randomized blocks, with two wheat cultivars (BRS 264 and BRS 394) and the presence or absence of $\mathrm{Si}$ as the four treatments. Each treatment was replicated six times. The choice of cultivars was based on a previous study in which the effect of Si fertilization had been evaluated for three seasons with the cultivar BRS 264 (Oliveira, 2016); this cultivar served as a comparison for BRS 394, a more recently released commercial variety.

The experimental units consisted of ten $5 \mathrm{~m}$ long rows, spaced $0.17 \mathrm{~m}$ apart. Evaluations were done in the four central rows, excluding from sampling $0.5 \mathrm{~m}$ at the ends of each row. Thus, the plot total area was $8.5 \mathrm{~m}^{2}$, the evaluation area was $2.72 \mathrm{~m}^{2}$, and the total area of each the experiment was $300 \mathrm{~m}^{2}$. 
Observations were made during plant development; as soon as aphids were detected, the number of aphids in ten randomly selected tillers in each plot were estimated. Evaluations were, hence, started 45 days after sowing (DAS), at the end of the stem extension stage when the sheath of the last leaf was completely grown and the ear swollen but not yet visible (Large, 1954). Evaluations were made once per week for six weeks, at which point the plant lost moisture and aphid numbers were consequently reduced.

Upon crop maturity, five plants in each plot were collected before harvest, dried in a forced-air oven and ground to determine Si percentage in the vegetable tissue, according to G. H. Korndörfer, Pereira and Nolla (2004). Harvest was done manually, picking only the heads in the evaluation area. At this moment, plant height was measured in 10 arbitrarily selected plants per plot. Subsequently, the heads were threshed, and the kernels separated from other materials. Kernel moisture and hectoliter weight $\left(\mathrm{g} / \mathrm{cm}^{3}\right)$ were determined using the portable moisture analyzer (model G650i), and yield was estimated as metric tons $(1000 \mathrm{~kg})$ per ha, using $13 \%$ moisture level as the standard.

Data were tested for normality of the statistical residues using the Shapiro-Wilk's test and for homogeneity of the variances using Levene's test. Data on leaf Si concentration (\%) and plant height were $\log$ transformed to meet these assumptions and analyzed with three-way ANOVA, considering wheat cultivars, Si fertilization level, location, and their interactions as the independent variables. The averages were compared using Tukey's test at 0.05 probability. A Mixed Generalized Linear Model (GLMM) with a negative binomial distribution and logistics link function was adjusted, considering the effects of cultivars, silicon, location, and the logistic adjustment of dates as fixed factors. The effects of collections performed within each location, in each block, and with time subdivision were considered as random, adopting inflated zero for the dates collected (Carvalho, Santana, \& Sampaio, 2020). The effects considered significant by the deviance analysis $\left(\mathrm{X}^{2}<0.05\right)$ were compared using the Tukey test. For $S$. graminum, a similar model was adjusted, differing in that it did not have a location effect.

\section{Results and Discussion}

\section{Leaf silicon content}

The interaction among production localities, silicon presence, and cultivar was not significant for leaf $\mathrm{Si}$ content in wheat plants $(\mathrm{F}=1.340 ; \mathrm{df}=2 ; \mathrm{P}=$ $0.2722)$, nor was the interaction between production locality and $\mathrm{Si}(\mathrm{F}=0.325 ; \mathrm{df}=2 ; \mathrm{P}=0.7239)$ or that between cultivar and $\mathrm{Si}(\mathrm{F}=1.118 ; \mathrm{df}=2 ; \mathrm{P}=$ $0.2959)$. The analysis of the factors alone indicated that cultivar $(\mathrm{F}=0.023 ; \mathrm{df}=2 ; \mathrm{P}=0.8793)$ did not affect leaf $\mathrm{Si}$ content, but that both cultivars had higher leaf Si contents after soil silicon fertilization $(\mathrm{F}=6.391 ; \mathrm{df}=1 ; \mathrm{P}=0.0151)$. The application of $\mathrm{Si}$ in the soil led to a $0.22 \%$ increase in Si leaf content at UFU, $0.48 \%$ at IFTM, and $0.31 \%$ at UFMG; the increments observed in the current experiment were ideal, since increments of $0.35 \%$ (Oliveira et al., 2020) and $0.60 \%$ (Boer, Sampaio, \& Pereira, 2019) in leaf silicon content have been shown to reduce aphid population in previous studies. Leaf Si content was greater at IFTM than at the other two locations, which did not differ from each other $(\mathrm{F}=3.605$; df $=1 ; \mathrm{P}=0.0353)$. In the IFTM location, BRS 264 responded more than BRS 394 to Si application in terms of leaf Si content (Figure 2). 


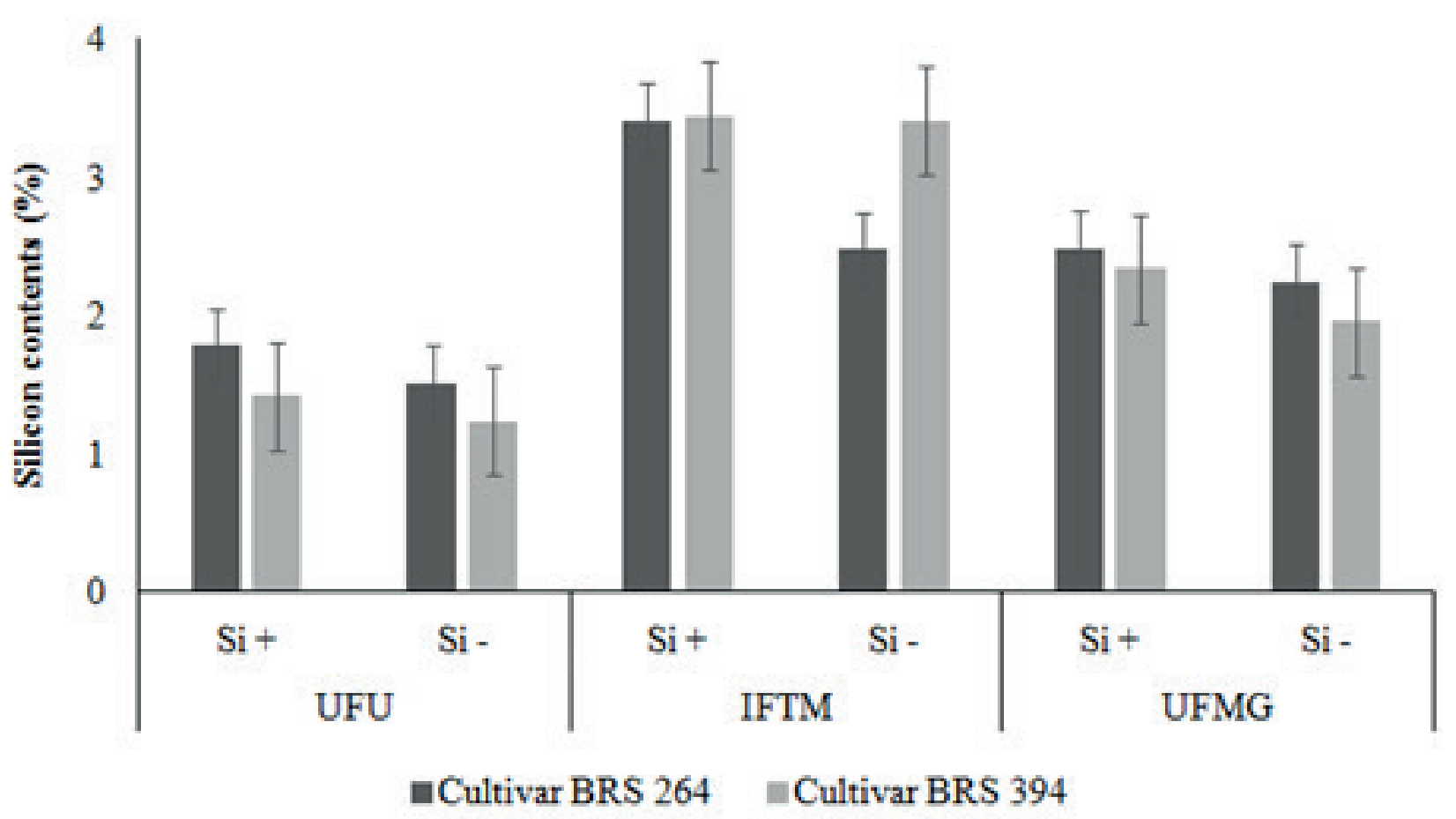

Figure 2. Silicon contents (average \pm standard error) of two wheat cultivars with $(\mathrm{Si}+)$ or without ( $\mathrm{Si}$-) soil $\mathrm{Si}$ fertilization at $493.5 \mathrm{~kg} \mathrm{ha}^{-1}$ in three localities in the State of Minas Gerais, Brazil: Capim Branco farm at UFU and experimental area of IFTM in the county of Uberlândia, and the experimental area of UFMG in Montes Claros. Averages are different at 0.05 by Tukey's test, when compared with the same cultivar with or without $\mathrm{Si}$ in the same planting location. Averages of leaf Si contents were greater at IFTM $(\mathrm{P}<0.05)$ than at the other growth localities.

\section{Accumulated degree-days at study sites}

Over the 17-week wheat growing period, the number of day-degrees accumulated at UFMG (Montes Claros) was 2,114 degree-days, while at UFU (Uberlândia) it was 2,044 degree-days (Figure 1). The time needed for wheat maturation differed inversely to the number of day-degrees at the sites. Crop development was faster at UFMG, where 72 days were required from sowing to maturation and 86 days from sowing to harvest, than at Uberlândia, where 79 days were needed for maturation and 102 days for harvest at UFU and 100 days for maturation and 117 days for harvest at IFTM (Figure 1).

\section{Aphid population and species}

The aphid species found on wheat at the study sites were $S$. avenae, $S$. graminum and $R$. padi. Only $S$. avenae had a high population density at all three locations; as such, location as a factor was included in the statistical analysis only for this aphid species. In contrast, it was possible to analyze the number of $S$. graminum per tiller only at UFMG, since this species was found at levels that were too low for analysis at the two locations in Uberlândia (UFU and IFTM). Individuals of the least common species, $R$. padi, appeared sporadically and at low levels; as such, this species was removed from the statistical analyses. Both at UFU and IFTM, the sum of the populations of $S$. graminum and $R$. padi 
represented approximately 3\% of the total aphid population per evaluation, while at UFMG the population of $R$. padi represented, on average, less than $1 \%$ of aphids in total.

There are no previous studies about aphid populations on wheat plants in the regions of Triângulo Mineiro and northern Minas Gerais; nevertheless, $R$. maidis, $R$. padi, and $S$. avenae have been capture by yellow traps on wheat fields at Triângulo Mineiro (Marsaro et al., 2016). In the present study, $S$. avenae was the main aphid species found in wheat plants. In Minas Gerais Cerrado the main winter crops are poorly cultivated (Castañeda, Figueroa, Fuentes-Contreras, Niemeyer, \& Nespolo, 2009). This scenario is similar to that observed in Rio Grande do Sul state, in the southern region of Brazil, where in the 1970 's, before the increase in oat production areas $S$. avenae was the most abundant pest reported, exceeding 90 insects/plant (Rebonatto et al., 2015). However, with the increase in winter crop species like rye, barley, wheat, triticale, and principally oat and corresponding cultivation areas in the southern regions of Brazil, R. padi became the most important species of aphids on winter crops in Rio Grande do Sul, increasing from less than 1\% in the 1970 's to more than $57 \%$ of the total aphids in wheat (Lau et al., 2009; Rebonatto et al., 2015). In the state of Paraná, the intermediate region between Rio Grande do Sul and Minas Gerais
Cerrado, S. avenae (Zanini, Alves, Menezes, \& Prestes, 2006; Bortolotto, Menezes, Hoshino, \& Campos, 2016) or R. padi (Bortolotto, Menezes, \& Hoshino, 2015) have been reported as the principal aphid species in wheat crops.

No interaction was detected among the factors date, location, cultivar, and Si fertilization on the number of $S$. avenae per tiller $\left(\mathrm{F}_{\text {chisq }}=0.0614\right.$; df $\left.=2 ; \mathrm{P}_{\text {chisq }}=0.9698\right)$. In contrast, the interactions among cultivar, date, and location $\left(\mathrm{F}_{\text {chisq }}=6.3216\right.$; $\left.\mathrm{df}=2 ; \mathrm{P}_{\text {chisq }}=0.0424\right)$ and among locale and date $\left(\mathrm{F}_{\text {chisq }}=33.6117 ; \mathrm{df}=2 ; \mathrm{P}_{\text {chisq }}=5.027^{-8}\right)$ were significant. Silicon (Figures 3A, 3B, and 3C) did not affect the density of the $S$. avenae population $\left(\mathrm{F}_{\text {chisq }}<0.0001 ; \mathrm{df}=1 ; \mathrm{P}_{\text {chisq }}=0.9966\right)$. At UFMG, densities of $S$. graminum per tiller showed no interaction effects among evaluation date, cultivar, and presence of $\mathrm{Si}$ fertilization $\left(\mathrm{F}_{\text {chisq }}=3.176\right.$; $\mathrm{df}=$ $\left.5 ; \mathrm{P}_{\text {chisq }}=0.6728\right)$, nor among evaluation date and $\mathrm{Si}\left(\mathrm{F}_{\text {chisq }}=0.568 ; \mathrm{df}=5 ; \mathrm{P}_{\text {chisq }}=0.9894\right)$ or cultivar and $\mathrm{Si}\left(\mathrm{F}_{\text {chisq }}=0.008 ; \mathrm{df}=1 ; \mathrm{P}_{\text {chisq }}=0.9296\right)$. The factors $\mathrm{Si}\left(\mathrm{F}_{\text {chisq }}=0.001 ; \mathrm{df}=1 ; \mathrm{P}_{\text {chisq }}=0.9822\right)$ and cultivar $\left(\mathrm{F}_{\text {chisq }}=5.752 ; \mathrm{df}=1 ; \mathrm{P}_{\text {chisq }}=0.0165\right) \mathrm{did}$ not affect populations of $S$. graminum per tiller. On the other hand, date $\left(\mathrm{F}_{\text {chisq }}=52.395 ; \mathrm{df}=5 ; \mathrm{P}_{\text {chisq }}=\right.$ $\left.4.5^{-10}\right)$ affected population density. The population peak of $S$. graminum at UFMG occurred before wheat flowering $(5.12 \pm 1.11)$ and was 6.83 times bigger than the average of the other evaluations $(0.75 \pm 0.01)$ (Figure 3D). 

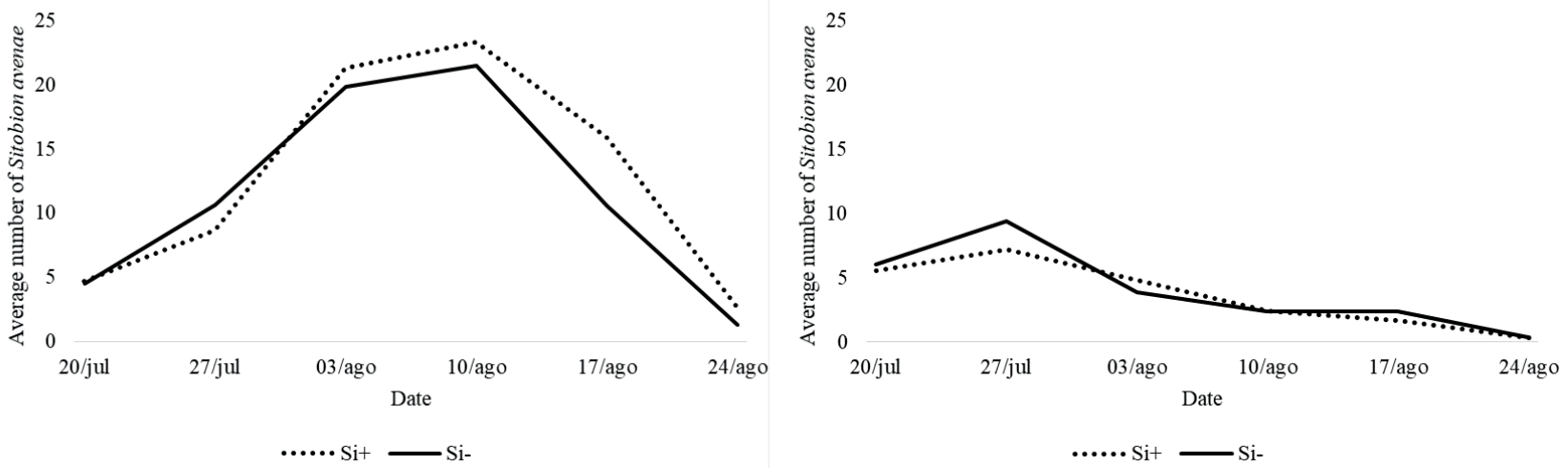

C
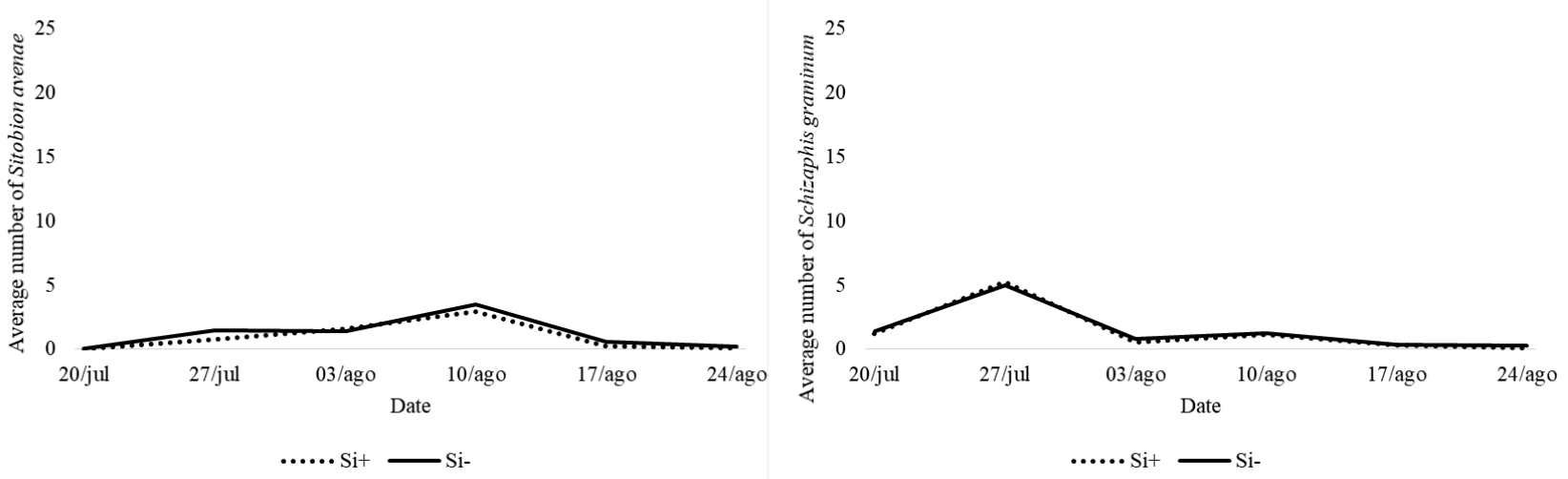

Figure 3. Number of Sitobion avenae and Schizaphis graminum (average per tiller) in wheat plants with ( $\mathrm{Si}+$ ) or without (Si-) soil Si fertilization at $493.5 \mathrm{~kg} \mathrm{ha}^{-1}$ in three production locations in the State of Minas Gerais, Brazil. (A) S. avenae at Capim Branco farm, UFU, Uberlândia. (B) S. avenae at experimental area of IFTM, Uberlândia. (C) S. avenae at the experimental area of UFMG, Montes Claros. (D) S. graminum at the experimental area of UFMG, Montes Claros. Wheat plant phenological stages were as follows - Stage 10: in "boot", on July $7^{\text {th; }}$ Stage 10.5: flowering, on August 10 ${ }^{\text {th }}$; Stage 11: ripening, on August $24^{\text {th }}$.

No direct response was observed between silicon fertilization and populations of the aphids $S$. avenae or $S$. graminum feeding on wheat plants. Previous studies under laboratory and greenhouse conditions have found that the application of silicon reduced populations of these two aphid species (Basagli, Moraes, Carvalho, Ecole, \& Gonçalves Gervásio, 2003; Gomes, Moraes, Santos, \& Goussain, 2005; Dias et al., 2014). However, no previous field studies were available to serve as a comparison for our study. Silicon fertilization has been found to promote greater activity of plant defense systems, forming and releasing secondary compounds which can reduce potential insect population growth
(Chérif, Asselin, \& Bélanger, 1994; Basagli et al., 2003; Gomes et al., 2005; Mendonça, Tavares, Brunes, Monzón, \& Villela, 2013; Ye et al., 2013).

The trial at UFU was the only one in which aphid populations (Figure 3 and Figure 4) reached the economic threshold of 10 aphids per spike (Fronza, Campos, \& Riede, 2008). Before the ears began to swell, temperatures were mild i.e., within the ideal range (between 18 and $24{ }^{\circ} \mathrm{C}$ ) for aphid, including $S$. avenae, development in both Uberlândia and Montes Claros (Asin \& Pons, 2001; Conti, Bueno, Sampaio, \& Sidney, 2010; Conti, Bueno, Sampaio, \& Lenteren, 2011; Sampaio et al., 2017). In contrast, heat accumulation was greater at UFMG, 
reducing time needed for the growth of wheat plants and grain maturation (Figure 2). Besides having a direct effect on the aphids, the greater heat levels at this site shortened the wheat cycle, which could have resulted in less time for the aphids to find and colonize the plant (during the vegetative stage of wheat) and increase its population (during the reproductive stage of wheat) (Nicol \& Wratten, 1997; Gianoli, 2000; Silva et al., 2013).

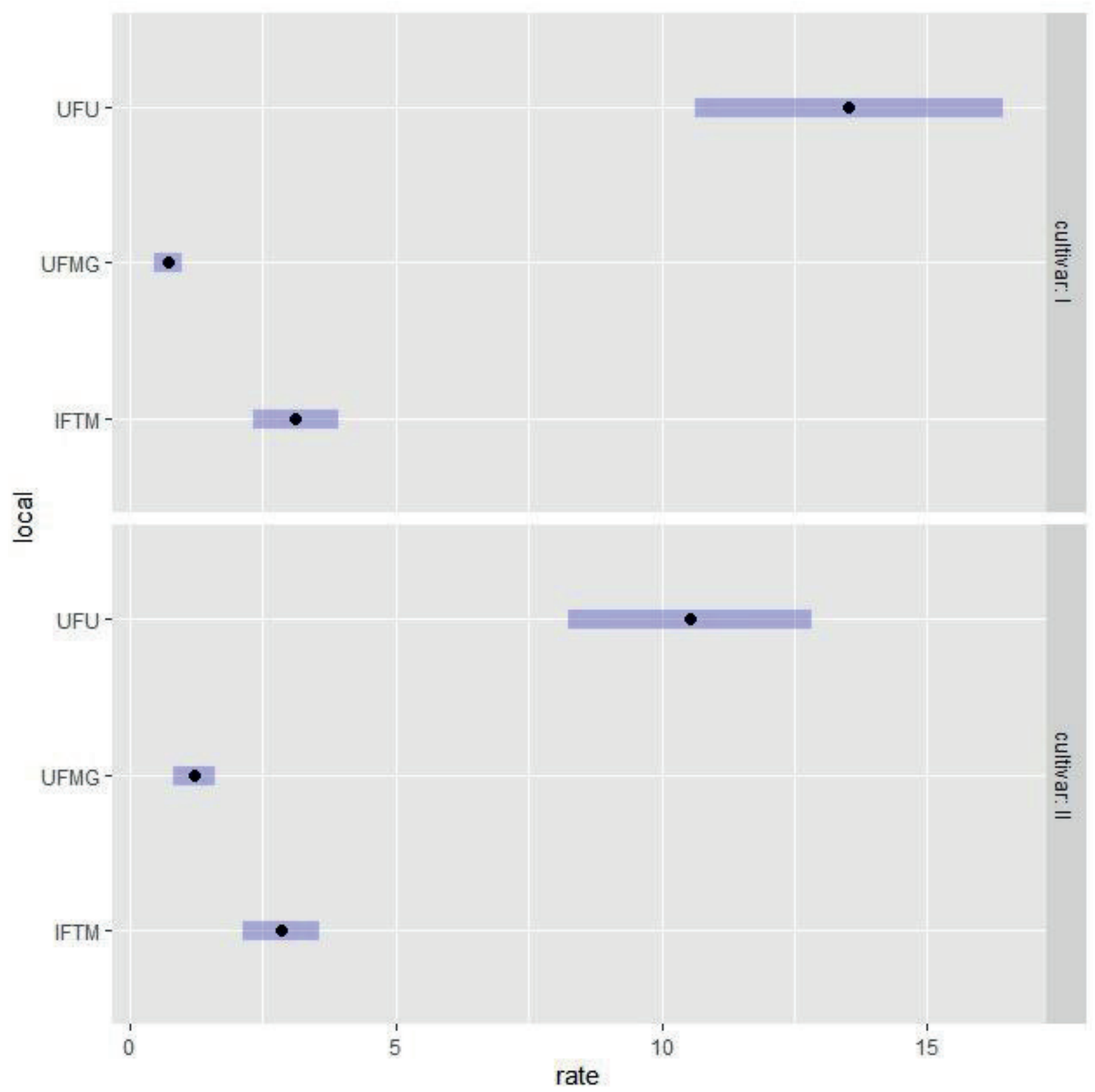

Figure 4. Number of Sitobion avenae (average [rate] \pm standard error) per tiller in two wheat cultivars (I - BRS 264; II - BRS 394), in three production locations in the State of Minas Gerais, Brazil: Capim Branco farm at UFU and experimental area of IFTM in the county of Uberlândia, and the experimental area of UFMG in Montes Claros. The averages of the three location are different from each other $(\mathrm{P}<0.05$, Tukey test $)$; averages of the cultivars at UFMG are different $(\mathrm{P}<0.05$, Tukey test $)$ when compared to each other. 
In this study, independent of the cultivar, the greatest populations of the aphid $S$. avenae per tiller $(13.526 \pm 1.477$ and $10.538 \pm 1.167)$ (Figure 3 and Figure 4) was in UFU, followed by IFTM (3.133 \pm 0.406 and $2.856 \pm 0.371)$, and, finally, UFMG $(0.738$ \pm 0.130 and $1.212 \pm 0.201$ ) (Figure 3 and Figure 4).

The average number of $S$. avenae per tiller was not different between the cultivars at UFU $(\mathrm{F}=5.808 ; \mathrm{df}=2 ; \mathrm{P}=0.0609)$ and at IFTM $(\mathrm{F}=$ $1.323 ; \mathrm{df}=2 ; \mathrm{P}=0.3021)$. However, at $\mathrm{UFMG}$, the cultivar BRS 264 supported fewer $S$. avenae than BRS $394(\mathrm{~F}=8.420 ; \mathrm{df}=1 ; \mathrm{P}=0.0337)$. However, in another study, the cultivar BRS 264 has been found to be more susceptible to $S$. avenae than BRS 254, Embrapa 22, and BRS Timbaúva (Silva et al., 2013). Thus, it can be inferred that BRS 394 too is susceptible to $S$. avenae, since the populations of this aphid presented very similar numbers in both cultivars in two of the three cultivation localities.

\section{Plant height and yield}

The interaction among the factors location, cultivar, and $\mathrm{Si}$ fertilization $(\mathrm{F}=1.038 ; \mathrm{df}=2 ; \mathrm{P}=$ 0.3627 ) was not significant for plant height, nor was that between location and cultivar $(\mathrm{F}=0.115$; $\mathrm{df}=$ 2; $\mathrm{P}=0.8920)$, location and $\mathrm{Si}$ status $(\mathrm{F}=0.645$; $\mathrm{df}=1 ; \mathrm{P}=0.5293)$ or cultivar and $\mathrm{Si}$ status $(\mathrm{F}=$ 1.599; $\mathrm{df}=2 ; \mathrm{P}=0.2126$ ) (Figure 5). However, significant results were obtained for the interaction between height and location $(\mathrm{F}=42.373$; $\mathrm{df}=1 ; \mathrm{P}<$ 0.0001 ), in which wheat grown at UFU had smaller averages, followed by those grown at UFMG, while the tallest plants were obtained at IFTM (Figure 5). Wollenweber, Porter and Schellberg (2003) observed that temperatures over $25{ }^{\circ} \mathrm{C}$ reduced plant height and biomass accumulation in wheat plants due to a reduction in carbon assimilation.

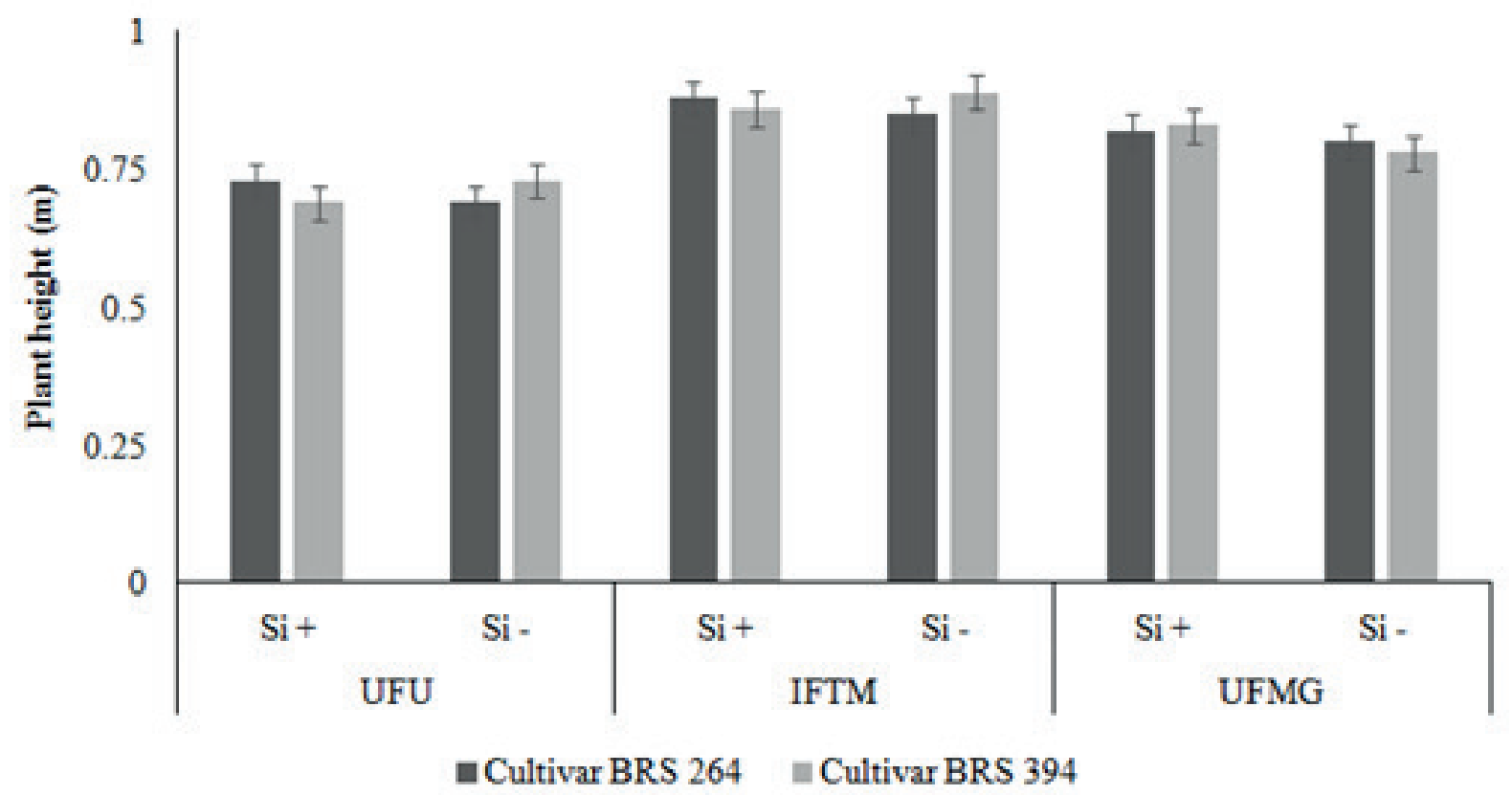

Figure 5. Plant height (average \pm standard error) of two wheat cultivars, with ( $\mathrm{Si}+$ ) or without ( $\mathrm{Si}-$ ) soil $\mathrm{Si}$ fertilization at $493.5 \mathrm{~kg} \mathrm{ha}^{-1}$ in three production location in the State of Minas Gerais, Brazil: Capim Branco farm, at UFU and experimental area of IFTM, in the county of Uberlandia, and at the experimental area of UFMG, in Montes Claros. Averages of the three cultivation locations differ from each other ( $\mathrm{P}<0.05$, Tukey's test). 
There was no interaction between productivity $(\mathrm{t}$ $\left.\mathrm{ha}^{-1}\right)$ among location, cultivar, and $\mathrm{Si}(\mathrm{F}=1.472$; df $=2 ; \mathrm{P}=0.2403$ ), or between location and cultivar $(\mathrm{F}=0.865 ; \mathrm{df}=2 ; \mathrm{P}=0.4278)$, location and $\mathrm{Si}(\mathrm{F}$ $=0.774 ; \mathrm{df}=2 ; \mathrm{P}=0.4672)$, cultivar and $\mathrm{Si}(\mathrm{F}=$ $0.001 ; \mathrm{df}=2 ; \mathrm{P}=0.9935)$, or the factors alone: cultivar $(\mathrm{F}=0.548 ; \mathrm{df}=1 ; \mathrm{P}=0.4630)$, silicon $(\mathrm{F}$ $=1.947 ; \mathrm{df}=1 ; \mathrm{P}=0.1698)$, or location $(\mathrm{F}=2.178$; $\mathrm{df}=1 ; \mathrm{P}=0.1251)$. Average yield was $2.30 \pm 0.12 \mathrm{t}$ $\mathrm{ha}^{-1}$ for treatments without Si fertilization and $2.52 \pm$ $0.08 \mathrm{t} \mathrm{ha}^{-1}$ for treatments with Si fertilization, which was still below the national average of $2.74 \mathrm{t} \mathrm{ha}^{-1}$ (CONAB, 2017). Cultivar BRS 264 was released with an expected productivity of $6.7 \mathrm{t} \mathrm{ha}^{-1}$ (Albrecht et al., 2007) and, in the county of Coromandel, Minas Gerais, $120 \mathrm{~km}$ away from Uberlândia and $400 \mathrm{~km}$ away from Montes Claros, yields of $6.5 \mathrm{t} \mathrm{ha}^{-1}$ have been recorded (Alvarenga, Soares, \& Santos, 2009); these amounts are both about 3.25 times greater than that obtained at UFU, which had the greatest yield in this study. Wheat yield did not respond to any of the factors analyzed, including silicate fertilization. In contrast, Mendonça et al. (2013), in controlled conditions in Pelotas, Rio Grande do Sul, observed that $\mathrm{Si}$ fertilization at $1,720 \mathrm{~kg} \mathrm{ha}^{-1}$ significantly increased the kernel number and yield of the wheat cultivar Fundacep Horizonte.

There were no significant interactions among any of the three factors for hectoliter weight of wheat $(\mathrm{F}=0.911 ; \mathrm{df}=2 ; \mathrm{P}=0.4095)$, nor between the interactions of locality and $\mathrm{Si}(\mathrm{F}=0.070 ; \mathrm{df}=$ $2 ; \mathrm{P}=0.9329)$, locality and cultivar $(\mathrm{F}=1.765 ; \mathrm{df}$ $=2 ; \mathrm{P}=0.1828)$ or cultivar and $\mathrm{Si}(\mathrm{F}=2.369 ; \mathrm{df}$ $=2 ; \mathrm{P}=0.1308)$ (Table 1$)$. The factor Si by itself $(\mathrm{F}=0.184 ; \mathrm{df}=1 ; \mathrm{P}=0.6697)$ was not significant for hectoliter weight. However, it can be stated that UFU presented the greatest averages of hectoliter weight $(\mathrm{F}=34.089 ; \mathrm{df}=1 ; \mathrm{P}<0.0001)$ and that the hectoliter weight was greater for the cultivar BRS 394 than for cultivar BRS $264(\mathrm{~F}=11.175 ; \mathrm{df}=1$; $\mathrm{P}=0.0017$ ) (Table 1). Hectoliter weight is the unit used for wheat at the Stock Exchange Market and has the base value of $78 \mathrm{~kg} \mathrm{hl}^{-1}$, which, in this study, was surpassed only by cultivar BRS 394 grown at UFU $\left(80.49 \pm 0.06 \mathrm{~kg} \mathrm{hl}^{-1}\right)$.

Table 1

Hectoliter weight $\left(\mathrm{kg} \mathrm{hl}^{-1}\right)$ (average \pm standard error) of two wheat cultivars with (Si+) or without (Si-) soil $\mathrm{Si}$ fertilization at $493.5 \mathrm{~kg} \mathrm{ha}^{-1}$ in three localities in the State of Minas Gerais, Brazil: Capim Branco farm at UFU and experimental area of IFTM, in the county of Uberlândia, and the experimental area of UFMG in Montes Claros

\begin{tabular}{ccccc}
\hline \multirow{2}{*}{ Locality } & Silicon & \multicolumn{3}{c}{ Cultivar } \\
\cline { 3 - 5 } & & BRS 264 & BRS 394 & Average \\
\hline \multirow{2}{*}{ UFU } & Si+ & $76.25 \pm 0.54$ & $81.03 \pm 0.18$ & $78.81 \pm 0.07 \mathrm{a}$ \\
& Si- & $78.03 \pm 0.33$ & $79.95 \pm 0.15$ & $73.22 \pm 0.05 \mathrm{~b}$ \\
\multirow{2}{*}{ IFTM } & Si+ & $71.35 \pm 0.56$ & $74.48 \pm 0.46$ & $72.03 \pm 0.07 \mathrm{~b}$ \\
& Si- & $71.75 \pm 0.36$ & $75.30 \pm 0.37$ & $73.34 \pm 0.24$ \\
\end{tabular}

Different letters, capital-case in the rows and lower-case in the final column, are different according to Tukey's test at 0.05 probability. 


\section{Conclusions}

The aphid $S$. avenae was the main aphid species found colonizing wheat plants in Uberlândia and Montes Claros, reaching the economic threshold only in Uberlândia. The aphids $S$. graminum and $R$. padi were also found at low population levels in wheat in all study locations. Silicon fertilization did not induce resistance in wheat to the aphid $S$. avenae, nor interfere with wheat yield. There were no yield differences for localities or cultivars; however, the location UFU and the cultivar BRS 394 had the higher average hectoliter weight.

\section{References}

Albrecht, J. C., Vieira, E. A., Silva, M. S., Andrade, J. M. V., Scheeren, P. L., Trindade, M. G.,... Yamanaka, C. H. (2007). Adaptabilidade e estabilidade de genótipos de trigo irrigado no Cerrado do Brasil Central. Pesquisa Agropecuária Brasileira, 42(12), $1727-$ 1734. doi: 10.1590/S0100-204X2007001200009

Alvarenga, C. B., Soares, J., Sobrinho, \& Santos, E. M. (2009). Comportamento de cultivares de trigo em diferentes densidades de semeadura sob irrigação indicadas para a região do Brasil Central. Bioscience Journal, 25(5), 98-107.

Asin, L., \& Pons, X. (2001). Effect of high temperature on the growth and reproduction of corn aphids (Hemiptera: Aphididae) and implications for their population dynamics on the Northeastern Iberian Peninsula. Environmental Entomology, 30(6), 11271134. doi: 10.1603/0046-225X-30.6.1127

Basagli, M. A. B., Moraes, J. C., Carvalho, G. A., Ecole, C. C., \& Gonçalves Gervásio, R. C. R. (2003). Effect of sodium silicate application on the resistance of wheat plants to green-aphids Schizaphis graminum (Rond.) (Hemiptera: Aphididae). Neotropical Entomology, 32(4), 659-663. doi: 10.1590/S1519$566 \times 2003000400017$

Boer, C. A., Sampaio, M. V., \& Pereira, H. S. (2019). Silicon-mediated and constitutive resistance to Rhopalosiphum maidis (Hemiptera: Aphididae) in corn hybrids. Bulletin of Entomological Research, 109(3), 356-364. doi: 10.1017/S0007485318000585

Bortolotto, O. C., Menezes, A. O. Jr., \& Hoshino, A. T. (2015). Aphidophagous parasitoids can forage wheat crops before aphid infestation, Paraná State, Brazil. Journal of Insect Science, 15(1), 1-4. doi: 10.1093/ jisesa/iev027
Bortolotto, O. C., Menezes, A. O. Jr., Hoshino, A. T., \& Campos, T. A. (2016). Distance from the edge of forest fragments influence the abundance of aphidophagous hoverflies (Diptera: Syrphidae) in wheat fields. Acta Scientiarum. Agronomy, 38(2), 157-164. doi: 10.4025/actasciagron.v38i2.27711

Carvalho, F. J., Santana, D. G. de, \& Sampaio, M. V. (2020). Modeling overdispersion, autocorrelation, and zero-inflated count data via generalized additive models and bayesian statistics in an aphid population study. Neotropical Entomology, 49(1), 40-51. doi: 10.1007/s13744-019-00729-x

Castañeda, L. E., Figueroa, C. C., Fuentes-Contreras, E., Niemeyer, H. M., \& Nespolo, R. F. (2009). Energetic costs of detoxification systems in herbivores feeding on chemically defended host plants: a correlational study in the grain aphid, Sitobion avenae. Journal of Experimental Biology, 212(8), 1185-1190. doi: 10.1242/jeb.020990

Chérif, M., Asselin, A., \& Bélanger, R. R. (1994). Defense responses induced by soluble silicon in cucumber roots infected by Pythium spp. Phytopathology, 84(3), 236-242.

Companhia Nacional do Abastecimento (2017). Décimo segundo levantamento. acompanhamento da safra brasileira de grãos (ed. rev.) Brasília, DF: Author.

Conti, B. F. de, Bueno, V. H. P., Sampaio, M. V., \& Lenteren, J. C. (2011). Development and survival of Aulacorthum solani, Macrosiphum euphorbiae and Uroleucon ambrosiae at six temperatures. Bulletin of Insectology, 64(1), 63-68.

Conti, B. F. de, Bueno, V. H. P., Sampaio, M. V., \& Sidney, L. A. (2010). Reproduction and fertility life table of three aphid species (Macrosiphini) at different temperatures. Revista Brasileira de Entomologia, 54(4), 654-660. doi: 10.1590/S008556262010000400018

Dias, P. A. S., Sampaio, M. V., Rodrigues, M. P., Korndörfer, A. P., Oliveira, R. S., Ferreira, S. E., \& Korndörfer, G. H. (2014). Induction of resistance by silicon in wheat plants to alate and apterous morphs of Sitobion avenae (Hemiptera: Aphididae). Environmental Entomolgy, 43(4), 949-956. doi: 10. 1603/EN13234

Farias, A. R., Mingoti, R., Holler, W. A., Spadotto, C. A., Lovisi, E., Fo., Mori, C. de,... Silva, M. S. E. (2016). Potencial de produção de trigo no Brasil a partir de diferentes cenários de expansão da área de cultivo. Passo Fundo, RS: EMBRAPA Trigo. 
Fischer, T., Beyerlee, D., \& Edmeades, G. (2014). Crop yields and global food security. Will yield increase continue to feed the world? Monograph, Australian Centre for International Agricultural Research, Canberra, Australia.

Fronza, V., Campos, L. A. C., \& Riede, C. R. (2008). Informações técnicas para a safra 2008: trigo e triticale. Londrina: EMBRAPA Soja.

Gianoli, E. (2000). Competiton in cereal aphids (Homoptera: Aphididae) on wheat plants. Environmental Entomology, 29(2), 213-219. doi: 10.1093/ee/29.2.213

Gomes, F. B., Moraes, J. C., Santos, C. D., \& Goussain, M. M. (2005). Resistance induction in wheat plants by silicon and aphids. Scientia Agricola, 62(6), 547551. doi: 10.1590/S0103-90162005000600006

Keeping, M. G., Kvedaras, O. L., \& Bruton, A. G. (2009). Epidermal silicon on sugarcane: cultivar differences and role in resistance to sugarcane borer Eldana saccharina. Environmental and Experimental Botany, 66(1), 54-60. doi: 10.1016/j. envexpbot.2008.12.012

Köppen, W. (1948). Climatologia: con un estudio de los climas de la terra. México: Fondo de Cultura Economica.

Korndörfer, A. P., Grisoto, E., \& Vendramin, J. D. (2011). Induction of insect plant resistance to the spittlebug Mahanarva fimbriolata Stål (Hemiptera: Cercopidae) in sugarcane by silicon application. Neotropical Entomology, 40(3), 387-392. doi: 10.1590/S1519$566 \times 2011000300013$

Korndörfer, G. H., Pereira, H. S., \& Nolla, A. (2004). Análise de silício no solo, planta e fertilizante. (Boletim Técnico, 2.). Uberlândia: GPSi-ICIAGUFU.

Large, E. C. (1954). Growth stages in cereals illustration of the Feekes scale. Plant Pathology, 3(4), 128-129. doi: 10.1111/j.1365-3059.1954.tb00716.x

Lau, D., Pereira, P. R. V. da S., Salvadori, J. R., Schons, J., Parizoto, G., \& Mar, T. B. (2009). Ocorrência do Barley/Cereal yellow dwarf virus e seus vetores em cereais de inverno no Rio Grande do Sul, Santa Catarina, Paraná e Mato Grosso do Sul em 2008. (EMBRAPA Trigo, Comunicado Técnico online, 256). Passo Fundo: EMBRAPA Trigo.

Luo, Q. (2011). Temperature thresholds and crop production: a review. Climatic Change, 109(3-4), 583-98. doi: 10.1007/s10584-011-0028-6
Ma, J., \& Takahashi, E. (1990a). Effect of silicon on the growth and phosphorus uptake of rice. Plant and Soil, 126(1), 115-119. doi: 10.1007/BF00041376

Ma, J., \& Takahashi, E. (1990b). The effect of silicic acid in a P-deficient soil. Plant and Soil, 126(1), 121-125.

Marafon, A. C., \& Endres, L. (2011). Adubação silicatada em cana-de-açúcar. Aracaju, SE, EMBRAPA Tabuleiros Costeiros.

Marsaro, A. L., Jr., Ciociola, A. I., Jr., Raizel, C. B. E., Lira, N. L. A. de, Pereira, P. R. V. da S., Lau, D.,... Soares, J., Sobrinho. (2016). Levantamento de espécies de afídeos e parasitoides associadas à cultura do trigo no cerrado mineiro. Anais da Reunião da Comissão Brasileira de Pesquisa de Trigo e Triticale, Londrina, PR, Brasil.

Mendonça, A. O., Tavares, L. C., Brunes, A. P., Monzón, D. L. R., \& Villela, F. A. (2013). Acúmulo de silício e compostos fenólicos na parte aérea de plantas de trigo após a adubação silicatada. Bioscience Journal, 29(5), 1154-1162.

Nicol, D., \& Wratten, S. D. (1997). The effect of hydroxamic acid concentration at late growth stages of wheat on the performance of the aphid Sitobion avenae. Annals of Applied Biology, 130(3), 387-396. doi: 10.1111/j.1744-7348.1997.tb07669.x

Oliveira, R. S. (2016). Silício na indução de resistência à Sitobion avenae (Fabricius, 1775) (Hemiptera: Aphididae), na produtividade do trigo e na produção de voláteis. Tese de doutorado, Universidade Federal de Uberlândia, Uberlândia, MG, Brasil.

Oliveira, R. S., Peñaflor, M. F. G., Gonçalves, F. G., Sampaio, M. V., Korndörfer, A. P., Silva, W. D., \& Bento, J. M. S. (2020). Silicon-induced changes in plant volatiles reduce attractiveness of wheat to the bird cherry-oat aphid Rhopalosiphum padi and attract the parasitoid Lysiphlebus testaceipes. Plos one, 15(4), e0231005. doi: 10.1371/journal. pone. 0231005

Porter, J. R., \& Gawith, M. (1999). Temperatures and the growth and development of wheat: a review. European Journal of Agronomy, 10(1), 23-26. doi: 10.1016/S1161-0301(98)00047-1

Rebonatto, A., Salvadori, J. R., \& Lau, D. (2015). Temporal changes in cereal aphids (Hemiptera: Aphididae) populations in Northern Rio Grande do Sul, Brazil. Journal of Agricultural Science, 7(10), 71-78. doi: 10.5539/jas.v7n10p71

Salvadori, J. R., \& Tonet, G. L. (2001). Manejo integrado dos pulgões de trigo. (EMBRAPA Trigo. Documentos, 34). Passo Fundo: EMBRAPA Trigo. 
Sampaio, M. V., Korndörfer, A. P., Pujade-Villar, J., Hubaide, J. E. A., Ferreira, S. E., Arantes, S. O.,... Caballero-López, B.A. (2017). Brassica aphid (Hemiptera: Aphididae) populations are conditioned by climatic variables and parasitism level: a study case of Triângulo Mineiro, Brazil. Bulletin of Entomological Research, 107(6), 410-418. doi: 10.1017/S0007485317000220

Santos, M., Junqueira, A. R., Sá, V. M. de, Zanúncio, J., \& Serrão, J. (2015). Effect of silicon on the morphology of the midgut and mandible of tomato leaf miner Tuta absoluta (Lepidoptera: Gelechiidae) larvae. Invertebrate Survival Journal, 12(1), 158165.

Silva, A. M., Sampaio, M. V., Oliveira, M. V., Korndörfer, A. P., Ferreira, S. E., Polastro, G. C., \& Dias, P. A. S. (2013). Antibiosis and non-preference of Sitobion avenae (F.) (Hemiptera: Aphididae) on leaves and ears of commercial cultivars of wheat (Triticum aestivum). Neotropical Entomology, 42(3), 304-310. doi: $10.1007 /$ s13744-013-0117-5

Stary, P., Sampaio, M. V., \& Bueno, V. H. P. (2007). Aphid parasitoids (Hymenoptera, Braconidae, Aphidiinae) and their associations related to biological control in Brazil. Revista Brasileira de Entomologia, 51(1), 107-118. doi: 10.1590/S0085-56262007000100018
United States Department of Agriculture (2017). Crop production reports. Washington, DC: Author. Retrieved from https://www.usda.gov

Wollenweber, B., Porter, J. R., \& Schellberg, J. (2003). Lack of interaction between extreme high temperature events at vegetative and reproductive growth stages in wheat. Journal of Agronomy and Crop Science, 189(3), 142-150. doi: 10.1046/j.1439037X.2003.00025.X

Ye, M., Song, Y., Long, J., Wang, R., Baerson, S. R., Pan, Z.,... Zeng, R. (2013). Priming of jasmonatemediated anti herbivore defense responses in rice by silicon. Proceedings of the National Academy of Science of the United States of America, 110(38), 3631-3639. doi: 10.1073/pnas.1305848110

Zanini, A., Alves, L. F., Menezes, A. D. O., Jr., \& Prestes, T. M. V. (2006). Aspectos ecológicos de Aphidius colemani Viereck (Hymenoptera: Aphidiidae) sobre a população de Sitobion avenae (Fabricius) (Hemiptera: Aphididae) na cultura de trigo em Medianeira, PR. Semina: Ciências Agrárias, 27(2), 185-198. 